\title{
Effectiveness of mid-infrared spectroscopy to predict the color of bovine milk and the relationship between milk color and traditional milk quality traits
}

\author{
A. McDermott, ${ }^{\dagger} \dagger$ G. Visentin, ${ }^{*} \dagger$ S. McParland, ${ }^{*}$ D. P. Berry, ${ }^{*}$ M. A. Fenelon, $\ddagger$ and M. De Marchi $\dagger^{1}$ \\ ${ }^{*}$ Teagasc Animal \& Grassland Research and Innovation Centre, Moorepark, Fermoy, Co. Cork, Ireland \\ †Department of Agronomy, Food, Natural Resources, Animals and Environment (DAFNAE), University of Padova, Viale dell'Università 16, \\ 35020 Legnaro (PD), Italy \\ $\ddagger$ Teagasc, Food Research Centre, Moorepark, Fermoy, Co. Cork, Ireland
}

\section{ABSTRACT}

The color of milk affects the subsequent color features of the resulting dairy products; milk color is also related to milk fat concentration. The objective of the present study was to quantify the ability of mid-infrared spectroscopy (MIRS) to predict color-related traits in milk samples and to estimate the correlations between these color-related characteristics and traditional milk quality traits. Mid-infrared spectral data were available on 601 milk samples from 529 cows, all of which had corresponding gold standard milk color measures determined using a Chroma Meter (Konica Minolta Sensing Europe, Nieuwegein, the Netherlands); milk color was expressed using the CIELAB uniform color space. Separate prediction equations were developed for each of the 3 color parameters $\left(\mathrm{L}^{*}=\right.$ lightness, $\mathrm{a}^{*}=$ greenness, $\mathrm{b}^{*}=$ yellowness) using partial least squares regression. Accuracy of prediction was determined using both cross validation on a calibration data set (n $=422$ to 457 samples) and external validation on a data set of 144 to 152 samples. Moderate accuracy of prediction was achieved for the $\mathrm{b}^{*}$ index (coefficient of correlation for external validation $=0.72$ ), although poor predictive ability was obtained for both $a^{*}$ and $\mathrm{L}^{*}$ indices (coefficient of correlation for external validation of 0.30 and 0.55 , respectively). The linear regression coefficient of the gold standard values on the respective MIRS-predicted values of $a^{*}, L^{*}$, and $b^{*}$ was $0.81,0.88$, and 0.96 , respectively; only the regression coefficient on $\mathrm{L}^{*}$ was different from 1 . The mean bias of prediction (i.e., the average difference between the MIRS-predicted values and gold standard values in external validation) was not different from zero for any of 3 parameters evaluated. A moderate correlation (0.56) existed between the MIRS-predicted $\mathrm{L}^{*}$ and $\mathrm{b}^{*}$ indices, both of which were weakly correlated with the $a^{*}$ index. Milk

Received September 21, 2015

Accepted December 28, 2015.

${ }^{1}$ Corresponding author: massimo.demarchi@unipd.it fat, protein, and casein were moderately correlated with both the gold standard and MIRS-predicted values for $b^{*}$. Results from the present study indicate that MIRS data provides an efficient, low-cost screening method to determine the $b^{*}$ color of milk at a population level. Key words: cow milk, yellowness, Fourier transform infrared, grazing system

\section{INTRODUCTION}

Product color is one of the primary factors considered by consumers when making purchasing decisions, as it is often an indicator of ripeness, freshness, food safety, and attractiveness in the food industry (Hutchings, 1994). It is well known that milk color influences the color features of the subsequent dairy products, while also being related to the fat content of the milk (Winkelman et al., 1999). Differences in milk color can also be related to the presence of abnormalities in milk; for example, mastitis attributable to Streptococcus esculin infection causes milk to have a more reddish/yellowish color, whereas mastitis due to Streptococcus dysgalactiae also leads to a change in milk color (Espada and Vijverberg, 2002).

The white color of milk is a function of the milk's physical structure; the dispersion of both casein micelles and fat globules in the milk is responsible for the diffusion of incident light and is related to lightness (L*; Raty and Peiponen, 1999). The natural pigmentations from carotenoids, protein, and riboflavin are also associated with the white color of milk. Milk with a low carotenoid content, high protein, and high riboflavin tends to be whiter (Solah et al., 2007), or in other words have a greater $\mathrm{L}^{*}$ index value.

The yellow color (yellowness index; $\mathbf{b}^{*}$ ) of bovine milk is closely related to the level of $\beta$-carotene and fat content; a greater milk fat and $\beta$-carotene content results in an incremental increase to the $\mathrm{b}^{*}$ index of milk, hence the milk will have a more yellow color. Feeding and selective breeding of cows may be used to alter the carotenoid level and thus color of dairy products (Norieze et al., 2006b). Cows fed grass silage 
tend to produce milk with yellower fat and greater $\beta$-carotene content than milk produced by cows on a hay diet (Noziere et al., 2006a; Calderon et al., 2007). Breeds of cows, such as Jerseys, that produce milk with a greater carotenoid and fat content, produce more yellow color milk than breeds such as Holstein-Friesians (Winkelman et al., 1999). Loss of carotenoids from milk is minimal when transferred into butter and cheese, therefore also contributing to the yellow coloration of these dairy products.

Yellower dairy products may be considered favorable or unfavorable depending on the target market. For example, yellower products are considered an unfavorable attribute in Middle Eastern dairy markets (Keen and Wilson, 1992). However, in Europe, a yellower color is favorable in high-fat dairy products such as butter and full-fat cheeses (Casalis et al., 1972; Hutchings, 1994).

Because the gold standard methods for the determination of milk color [i.e., Chroma Meter (Minolta, Osaka, Japan) or a NH310 Color Meter Milk (Shenzhen 3NH Technology Co. Ltd., Shenzhen, China)] or for the determination of milk carotenoid content, can be relatively costly and also require sub-sampling of milk for analysis, the use of an analytical system already in place (e.g., mid-infrared spectroscopy; MIRS) to determine milk color may be more logical. Mid-infrared spectroscopy is currently used by milk recording organizations worldwide to predict milk fat, protein, casein, and lactose concentration and has recently been used to predict more detailed milk composition traits (De Marchi et al., 2014) or animal traits (McParland et al., 2014). The use of MIRS to predict novel milk quality traits is therefore appealing because the mid-infrared spectrum is available at a negligible additional cost and may be undertaken as part of the routine quantification of other components in milk. Nevertheless, to our knowledge, no study has attempted to evaluate the potential of MIRS to predict milk color traits.

The aim of the present study was to evaluate the ability of MIRS to predict milk color-related traits and to estimate the correlations between these milk color traits and a selection of traditional milk quality traits.

\section{MATERIALS AND METHODS}

\section{Milk Sample Collection}

Between August 2013 and August 2014, inclusive, 730 milk samples from 621 cows were obtained from 7 research farms operated by the Teagasc Animal and Grassland Research and Innovation Centre (Moorepark, Fermoy, Co. Cork, Ireland). Milk composition was recorded weekly using a MilkoScan FT6000 (Foss Electric A/S, Hillerød, Denmark), and the resulting spectrum, containing 1,060 transmittance data in the mid-infrared region between 900 and $5,000 \mathrm{~cm}^{-1}$, was stored. Following MIRS analysis, the milk samples were stored at $4^{\circ} \mathrm{C}$ for further analysis. Samples were selected to maximize diversity of breed [Holstein-Friesian $(\mathrm{n}=454)$, Jersey $(\mathrm{n}=117)$, Norwegian Red $(\mathrm{n}=15)$, and crossbreds ( $\mathrm{n}$ $=144$ )], stage of lactation ( 5 to $375 \mathrm{~d}$ in milk), milking time (i.e., a.m. or p.m. milking), and parity (1 to 11). Samples with preservative added $(\mathrm{n}=129)$ were not considered in the present study for the determination of milk color. The final data set used in the present study comprised 601 milk samples, 461 of which were from spring-calving cows fed a predominantly grazed grass-based diet and the remaining 140 samples were from autumn-calving cows fed a TMR diet in the early stages of lactation.

\section{Gold Standard Milk Color Determination}

Milk color was measured using a Chroma Meter CR400 (Konica Minolta Sensing Europe, Nieuwegein, the Netherlands) with a closed cone, set on the $L^{*} a^{*}$ $b^{*}$ system, and the Chroma meter was calibrated on a white tile. A 10-mL sub-sample of each milk sample was measured in a cuvette and expressed using the CIE-L* $a^{*} b^{*}$ uniform color space (CIELAB, 1976). The CIE$\mathrm{L}^{*} \mathrm{a}^{*} \mathrm{~b}^{*}$ plots the color coordinates in a uniform color space, which has an $\mathrm{L}^{*}, \mathrm{a}^{*}$, and $\mathrm{b}^{*}$ axis, with $\mathrm{L}^{*}$ (lightness; on a scale from 0 to 100 , where $0=$ black and 100 $=$ white), $\mathrm{a}^{*}$ (where $-\mathrm{a}^{*}$ has a green color and $+\mathrm{a}^{*}$ has a red color), and $b^{*}$ (where $-b^{*}$ has a blue color and $+b^{*}$ has a yellow color). The more different from zero or the greater the absolute value is, the stronger the color (i.e., a sample with an absolute value close to zero has a lighter color than a sample with an absolute value close to 100).

\section{Data Analysis}

Outlier samples were considered to be samples with a gold standard value $>3$ from the mean. No $L^{*}$ or $b^{*}$ indices outliers were removed, but 28 outliers were removed based on the a* index. All 3 milk color traits were normally distributed. Descriptive statistics were calculated within the Holstein-Friesian and Jersey breeds separately, as well as across all breeds combined and within season. The differences between the means of Holstein Friesian and Jersey cows and between the means of autumn and spring cows were derived using ANOVA in Microsoft Excel (Microsoft Corp., Redmond, WA). Spectral data were transformed from transmittance to linear absorbance using a logarithmic transformation of the reciprocal of the wavelength values (Soyeurt et al., 2011). Prediction models were developed using un- 
treated spectra. Mid-infrared spectroscopy models were developed to predict each color trait separately using partial least squares regression (Proc PLS, SAS Institute Inc., Cary, NC). Spectral regions considered were from 926 to $1,580 \mathrm{~cm}^{-1}, 1,717$ to $2,986 \mathrm{~cm}^{-1}$, and 3,696 to $3,808 \mathrm{~cm}^{-1}$, determined based on the observed loadings for each wavelength from preliminary analyses.

Accuracy of the prediction equations was determined using external validation, whereby $25 \%$ of data was excluded from equation calibration; these data were used in the independent validation data set. This procedure was repeated 3 times, using a different $25 \%$ of the data in the validation data set each time. Samples were selected for the validation data set to represent variation similar to that present in the gold standard data in the calibration data set used to develop the prediction equations. For each prediction model, the data set was sorted by the trait of interest. The first sample and every fourth sample thereafter were included in the validation data set for the first iteration; for the second iteration the second sample and every fourth sample thereafter was chosen for the validation data set, with a similar procedure used for the third and fourth iteration. No cow was represented in both the calibration data set and validation data set in a given iteration.

The criteria used to determine the accuracy of the MIRS predictive models were the coefficient of correlation of cross validation $\left(\mathbf{r}_{\mathbf{c}}\right)$ and external validation $\left(\mathbf{r}_{\mathrm{v}}\right)$, the root mean square error of cross validation (RMSEc) and external validation (RMSEv), the linear regression coefficient (b) of the MIRS-predicted values on the gold standard values of each trait, and the mean bias of prediction; the mean bias of prediction was calculated as the mean difference between the MIRS-predicted values and gold standard values in external validation. The ratio performance deviation, which is the ratio of the standard deviation of each trait to standard error of prediction, was also used as a measure of model predictive ability. Four validation data sets were created and then appended onto each other, and the $r_{c}, r_{v}$, root mean square error, $b(\mathrm{SE})$, and bias (SE) were calculated based on all 4 iterations combined. The average number of factors $(\# \mathrm{~L})$ used to build the prediction equations was the average num- ber from all 4 iterations rounded to the nearest whole number. Validation was performed within the HolsteinFriesian and Jersey breeds separately, as well as across all breeds combined. The Fisher's $r$ to $\mathrm{z}$ transformation was performed to determine if the accuracy of prediction differed between breed populations.

Furthermore, the $\mathrm{L}^{*}, \mathrm{a}^{*}$, and $\mathrm{b}^{*}$ indices were also predicted in external validation using the regression coefficients on milk fat, protein, and casein content estimated from the calibration data set.

Pearson correlations among the gold standard milk color traits, MIRS-predicted milk color traits, and MIRS-predicted fat, protein, and casein predicted using the Foss equations (MilkoScan FT+ Basic Calibrations Application Note 5373/Rev. 2 Part No. 6007 0238) were also estimated.

\section{RESULTS}

\section{Descriptive Statistics}

Descriptive statistics of the milk color traits are in Table 1 ; average values of $\mathrm{a}^{*}, \mathrm{~b}^{*}$, and $\mathrm{L}^{*}$ color indices were $-3.88,8.09$, and 81.57 , respectively. Jersey cows had a greater $(P<0.01)$ mean value for the yellow color of milk $\left(\mathrm{b}^{*}=10.03\right)$ than the Holstein-Friesian cows $\left(\mathrm{b}^{*}=7.48\right)$ and their milk also had a greater fat content. Spring-calving cows had a greater $(P<$ $0.01) b^{*}$ index than autumn calving cows (results not shown). The coefficient of variation was $2.24,13.65$, and $36.34 \%$ for $\mathrm{L}^{*}$, $\mathrm{a}^{*}$, and $\mathrm{b}^{*}$, respectively (Table 1 ).

\section{Color Prediction Accuracy}

Moderate accuracy of prediction was obtained for the $b^{*}$ index $\left(r_{v}=0.72\right.$; Table 2$)$, whereas poor prediction accuracy of prediction was obtained for both the $\mathrm{a}^{*}$ and $\mathrm{L}^{*}$ indices $\left(\mathrm{r}_{\mathrm{v}}=0.30\right.$ and $\mathrm{r}_{\mathrm{v}}=0.55$, respectively $)$. The accuracy of predicting the $a^{*}$ index was greater $(P<$ $0.05)$ for the Jersey population $\left(\mathrm{r}_{\mathrm{v}}=0.59\right)$ compared with external validation in just the Holstein-Friesian population $\left(\mathrm{r}_{\mathrm{v}}=0.09\right.$; Table 3$)$. The accuracy of predicting the $\mathrm{L}^{*}$ index was greater $(P<0.05)$ for the Holstein-Friesian population $\left(\mathrm{r}_{\mathrm{v}}=0.60\right)$ and the Jersey

Table 1. Mean, standard deviation, coefficient of variation, minimum (Min), and maximum (Max) for the gold standard color indices $\left(\mathrm{L}^{*}=\right.$ lightness; $\mathrm{a}^{*}=$ greenness; $\mathrm{b}^{*}=$ yellowness $)$ in the entire data set

\begin{tabular}{lcccccc}
\hline Trait & $\mathrm{n}$ & Mean & SD & \multicolumn{1}{c}{ CV } & Min & Max \\
\hline $\mathrm{L}^{*}$ & 601 & 81.57 & 1.83 & 2.24 & 74.05 & 87.78 \\
$\mathrm{a}^{*}$ & 573 & -3.88 & 0.53 & 13.65 & -5.78 & -2.10 \\
$\mathrm{~b}^{*}$ & 601 & 8.09 & 2.94 & 36.34 & -0.09 & 20.08 \\
\hline
\end{tabular}

${ }^{1}$ The greater the absolute value is, the stronger the color. 
Table 2. Fit statistics ${ }^{1}$ for the cross and external validation of prediction equations for color indices $\left(\mathrm{L}^{*}=\right.$ lightness; $\mathrm{a}^{*}=$ greenness; $\mathrm{b}^{*}=$ yellowness)

\begin{tabular}{|c|c|c|c|c|c|c|c|c|}
\hline Trait & \multicolumn{3}{|c|}{ Cross validation } & \multicolumn{5}{|c|}{ External validation } \\
\hline$\overline{L^{*}}$ & 15 & 1.46 & 0.63 & $0.02(1.57)$ & $0.88(0.05)$ & 1.57 & 0.55 & 1.20 \\
\hline$a^{*}$ & 9 & 0.51 & 0.37 & $-0.002(0.52)$ & $0.81(0.11)$ & 0.52 & 0.30 & 1.05 \\
\hline$b^{*}$ & 19 & 1.97 & 0.74 & $-0.005(2.03)$ & $0.96(0.04)$ & 2.03 & 0.72 & 1.45 \\
\hline
\end{tabular}

${ }^{1} \# \mathrm{~L}=$ average number of factors rounded to the nearest whole number; RMSE $=$ root mean square error; $\mathrm{r}_{\mathrm{c}}=$ correlation between true and predicted values in cross validation; $r_{v}=$ correlation between true and predicted values in external validation; $b=$ linear regression coefficient of predicted values on the gold standard values of each trait. RPD = ratio performance deviation.

population only $\left(\mathrm{r}_{\mathrm{v}}=0.73\right)$ compared with when all the breeds combined $\left(\mathrm{r}_{\mathrm{v}}=0.55\right)$ were included in external validation. The accuracy of predicting the $\mathrm{b}^{*}$ index was greater $(P<0.05)$ when all breeds combined were used in external validation $\left(\mathrm{r}_{\mathrm{v}}=0.72\right)$ compared with when just the Holstein-Friesian $\left(\mathrm{r}_{\mathrm{v}}=0.64\right)$ or Jersey $\left(\mathrm{r}_{\mathrm{v}}=\right.$ $0.66)$ was used. The ratio performance deviation values for the 3 milk color traits were less than 2 . The linear regression coefficients of the MIRS-predicted values on the gold standard values for $\mathrm{a}^{*}, \mathrm{~L}^{*}$, and $\mathrm{b}^{*}$ prediction models were $0.81,0.88$, and 0.96 , respectively; only the linear regression coefficient of $\mathrm{L}^{*}$ was different from 1 $(P<0.05)$. The bias of the prediction models, which is the average difference between MIRS-predicted values and gold standard values in external validation, was not different from zero $(P>0.05)$ for any of the 3 milk color parameters.

When milk fat, protein, and casein concentration combined were used as a predictor of the $\mathrm{a}^{*}, \mathrm{~L}^{*}$, and $\mathrm{b}^{*}$ indices, $\mathrm{r}_{\mathrm{v}}$ values $\left(0.18,0.48\right.$, and 0.60 for $\mathrm{a}^{*}, \mathrm{~L}^{*}$, and $\mathrm{b}^{*}$, respectively) were numerically lower $(P>0.05)$ than when predictions were based on the MIRS $(0.30$, 0.55 , and 0.72 for $\mathrm{a}^{*}, \mathrm{~L}^{*}$, and $\mathrm{b}^{*}$, respectively).

\section{Phenotypic Correlations}

A moderate correlation of 0.56 existed between the MIRS-predicted color traits $\mathrm{L}^{*}$ and $\mathrm{b}^{*}$, whereas the color parameter $\mathrm{a}^{*}$ was only weakly correlated with the other 2 color traits (Table 4). A moderate correlation (0.65) existed between the gold standard color traits $\mathrm{L}^{*}$ and $\mathrm{b}^{*}$, whereas both the gold standard and MIRS-predicted color parameter $a^{*}$ were only weakly correlated with the other 2 color traits (Table 4). A negative correlation existed between the gold standard $b^{*}$ and $a^{*}$ indices $(-0.17)$, as well as between the MIRS-predicted $b^{*}$ and $a^{*}$ indices $(-0.04)$. The color traits $\mathrm{b}^{*}$ and $\mathrm{L}^{*}$ were moderately correlated with MIRS-predicted milk fat, protein, and casein content (Table 4). The correlation between the gold standard $\mathrm{b}^{*}$ and MIRS-predicted fat (0.65) and between the MIRS-predicted $\mathrm{b}^{*}$ and MIRS-predicted fat (0.59) were similar. No strong correlations existed between the gold standard and MIRS-predicted color traits $\mathrm{L}^{*}, \mathrm{a}^{*}$, and $b^{*}$ with MIRS-predicted lactose. The MIRS-predicted protein and casein were strongly correlated, with casein constituting $77 \%$ of the variability in protein content.

Table 3. Number of records (n), root mean square error (RMSE), correlation coefficient between gold standard and mid-infrared spectroscopy (MIRS)-predicted values in external validation $\left(r_{v}\right)$ for all breeds, HolsteinFriesians only, and Jerseys only, tested using the split sample external validation

\begin{tabular}{lcrccc}
\hline Trait & $\mathrm{n}$ & Mean & $\mathrm{SD}$ & RMSE & $\mathrm{r}_{\mathrm{v}}$ \\
\hline All breeds & 120 & 81.57 & 1.83 & 1.57 & $0.55^{\mathrm{a}}$ \\
$\mathrm{L}^{*}$ & 143 & -3.88 & 0.53 & 0.52 & $0.30^{\mathrm{a}}$ \\
$\mathrm{a}^{*}$ & 120 & 8.09 & 2.94 & 2.03 & $0.72^{\mathrm{a}}$ \\
$\mathrm{b}^{*}$ & & & & & \\
Holstein-Friesians only & 98 & 81.57 & 1.91 & 1.55 & $0.60^{\mathrm{b}}$ \\
L* & 98 & -3.79 & 0.61 & 0.45 & $0.09^{\mathrm{b}}$ \\
$\mathrm{a}^{*}$ & 96 & 7.48 & 2.78 & 2.21 & $0.64^{\mathrm{a}}$ \\
$\mathrm{b}^{*}$ & & & & & \\
Jerseys only & 94 & 81.40 & 1.74 & 1.20 & $0.73^{\mathrm{ab}}$ \\
L $^{*}$ & 74 & -4.25 & 1.34 & 0.48 & $0.59^{\mathrm{a}}$ \\
$\mathrm{a}^{*}$ & 94 & 10.03 & 3.04 & 2.30 & $0.66^{\mathrm{a}}$ \\
$\mathrm{b}^{*}$ & &
\end{tabular}

$\overline{\mathrm{a}, \mathrm{b}}$ Coefficient of correlations within a color trait with different superscripts differ $(P<0.05)$ from each other. 


\section{DISCUSSION}

Feeding management could be an effective short-term method of increasing the yellow color in milk (Noziere et al., 2006a; Calderon et al., 2007), but selective breeding could be used as a long-term strategy. Moreover, management strategies to alter milk color may not always be feasible (e.g., feeding high-producing cows forage diets). Genetic selection, however, is cumulative and permanent but more importantly is amenable for implementation globally. Successful breeding programs are nonetheless predicated on access to large quantities of individual animal level information from which to generate estimated breeding values; this information should ideally be available at low cost. This was the motivation of the present study to evaluate the potential of the routinely used MIRS to predict milk color.

The mean absolute color values in the present study were greater than a study by Ordolff (2006) who compared milk color across a range of different somatic cell counts from 15 dairy cows in Germany. The b* values documented by Ordolff (2006) had negative values indicating the milk had a blue color; this was expected as the milk had a very low fat content compared with the milk samples analyzed in the present study. The greater fat content of milk used in the present study may be because the majority of the milk samples were from cows fed a grass-based diet. The yellow color of milk is positively associated with greater Lucerne (Larsen et al., 2013). Cows fed grass silage tend to produce milk with a greater fat and $\beta$-carotene content, and therefore a more yellow color, than milk produced by cows on a hay diet (Noziere et al., 2006a; Calderon et al., 2007).

A study by Phillips et al. (1995) that characterized low fat milk, calculated $\mathrm{L}^{*}, \mathrm{a}^{*}$, and $\mathrm{b}^{*}$ values based on Illuminant A from a Macbeth Color-Eye Spectrophotometer (Kollmorgen Instruments Corp., Newburgh, NY). The mean values for $a^{*}, b^{*}$, and $L^{*}$ observed by Phillips et al. (1995) at $2 \%$ fat content were -3.74 , 2.99 , and 81.11 , respectively. The $\mathrm{b}^{*}$ value documented by Phillips et al. (1995) was also lower than the $b^{*}$ value in the present study, where milk had a greater fat content.

Jersey cows had a greater $(P<0.01)$ mean value for the yellow color of milk $\left(b^{*}=10.03\right)$ than the HolsteinFriesian cows $\left(b^{*}=7.48\right)$, and their milk also had a greater fat content.

Spring-calving cows had a greater $(P<0.01) \mathrm{b}^{*}$ index than autumn-calving cows. This is expected as spring-calving cows were fed a grass-based diet, and therefore would have greater carotenoid and fat level in their milk, in comparison to autumn-calving cows that were kept indoors and fed hay or silage (Noziere et al., 2006a; Calderon et al., 2007). Although bovine milk color traits are related to the carotenoid level in milk and the transfer of these carotenoids from the blood to the milk (Noziere et al., 2006b; Gross et al., 2014), no information was available in the present study on the carotenoid content of the milk.

\section{Milk Mid-Infrared Spectroscopy Prediction of Color}

Because the ratio performance deviation values for the 3 milk color traits were less than 2 in the present study, the MIRS models should not be used for analytical purposes. According to Williams (2007), the prediction model for $\mathrm{a}^{*}$ is unstable as the slope deviates greatly from 1 (e.g., less than 0.85 or greater than 1.15), whereas the prediction equation for $b^{*}$ is expected to be stable because the linear regression coefficient of the true on predicted $\mathrm{b}^{*}$ was between 0.95 and 1.05 . The prediction of milk color indices by MIRS is not a consequence of direct prediction because the visible region of the electromagnetic spectrum (i.e., $350-800 \mathrm{~nm}$ ) is not part of the MIRS spectrum (De Marchi et al., 2014). As in the case of several innovative milk traits (e.g., milk coagulation traits, residual feed intake, methane emission), the prediction of color traits in the present study is most likely from indirect prediction of other components, for example fat content; the correlation

Table 4. Pearson correlations ${ }^{1}$ among the gold standard (below diagonal) and mid-infrared spectroscopy (MIRS)-predicted (above diagonal) color indices ( $\mathrm{L}^{*}=$ lightness; $\mathrm{a}^{*}=$ greenness; $\mathrm{b}^{*}=$ yellowness) and MIRSpredicted traditional milk quality traits

\begin{tabular}{|c|c|c|c|c|c|c|c|}
\hline Item & $\mathrm{L}^{*}$ & $a^{*}$ & $\mathrm{~b}^{*}$ & $\begin{array}{c}\text { Fat, } \\
\%\end{array}$ & $\begin{array}{c}\text { Protein, } \\
\%\end{array}$ & $\begin{array}{c}\text { Casein, } \\
\%\end{array}$ & $\begin{array}{c}\text { Lactose } \\
\%\end{array}$ \\
\hline $\mathrm{L}^{*}$ & - & 0.35 & 0.56 & 0.38 & 0.36 & 0.39 & 0.01 \\
\hline$a^{*}$ & 0.01 & - & -0.04 & -0.03 & -0.17 & -0.21 & -0.07 \\
\hline$b^{*}$ & 0.65 & -0.17 & - & 0.59 & 0.48 & 0.45 & -0.21 \\
\hline Fat, \% & 0.49 & -0.11 & 0.65 & - & 0.41 & 0.42 & -0.05 \\
\hline Protein, \% & 0.42 & -0.33 & 0.50 & 0.41 & - & 0.88 & -0.06 \\
\hline Casein, \% & 0.47 & -0.32 & 0.47 & 0.42 & 0.88 & - & 0.13 \\
\hline Lactose, \% & -0.01 & -0.07 & -0.29 & -0.05 & -0.06 & 0.13 & - \\
\hline
\end{tabular}

${ }^{1}$ Correlations $<|0.07|$ were not different from zero. 
between the gold standard $\mathrm{b}^{*}$ and fat content was 0.65 (Table 4). Mid-infrared spectroscopy is known to be able to accurately predict milk fat, protein, casein, and free fatty acids and is currently used by milk recording organizations worldwide. The greater accuracy of MIRS prediction model for $\mathrm{b}^{*}$ was also confirmed by the fewer number of model factors $\left(9,15\right.$, and 19 for $\mathrm{a}^{*}, \mathrm{~L}^{*}$, and $\mathrm{b}^{*}$, respectively). With partial least square regression, the pattern among wavelengths is reduced into fewer variables called loadings; each loading explains a part of the total variance and therefore the fewer the loading factors used the more robust the prediction equation is likely to be (De Marchi et al., 2013). The loadings also depict the molecular basis of the MIRS prediction, as peaks close to certain wavelengths are related to certain chemical bonds. Several spectral regions contributed to the prediction of the 3 color traits in the present study, and these were primarily the regions associated with lipids $\left(2,935,2,839,1,763 \mathrm{~cm}^{-1}\right)$, followed by the peaks at $968,1,146,1,180,1,331$, and $1,466 \mathrm{~cm}^{-1}$, which were attributed to $\mathrm{C}-\mathrm{O}, \mathrm{C}-\mathrm{C}, \mathrm{O}-\mathrm{C}-\mathrm{H}, \mathrm{C}-\mathrm{C}-\mathrm{H}$, and $\mathrm{C}-\mathrm{O}-\mathrm{H}$ bonding, respectively (De Marchi et al., 2013). This helps verify that the ability of MIRS to predict the $b^{*}$ color of milk may be (in part) an artifact of the MIRS detecting the milk fat concentration in the milk. Nonetheless, when the milk fat concentration alone was used as a predictor of the $\mathrm{b}^{*}$ index, an $\mathrm{r}_{\mathrm{v}}$ of only 0.33 was obtained, demonstrating that fat concentration alone is not predicting $\mathrm{b}^{*}$ but other components represented in the MIRS are also contributing to the prediction of $b^{*}$. Nonetheless, further studies should consider measuring the yellow milk color independent of the fat content. This could be achieved by gravity separation of a portion of the milk samples that have a high and low yellow color. The gravity cream could be added back in different combinations with gravity skim with low or high yellow color and gravity cream with low or high yellow color. This would enable the statistical model to better focus on information in the spectra that is related to color and reduce the confounding effect of fat concentration.

Although no study has evaluated the potential of MIRS in predicting milk color traits, several studies have investigated the use of near-infrared spectroscopy to predict color in other dairy products, especially cheese. Lucas et al. (2008) reported robust near-infrared spectroscopy prediction models for the color of fresh cheeses $(n=445)$, with $r_{v}$ values as high 0.96 for the color traits $\mathrm{a}^{*}$ and $\mathrm{b}^{*}$. Other studies measured color traits in foods such as meat (De Marchi et al., 2011) and wine (Urbano-Cuadrado et al., 2004). De Marchi et al. (2011) obtained $r_{v}$ values of $0.60,0.82$, and 0.88 for $\mathrm{L}^{*}, \mathrm{a}^{*}$, and $\mathrm{b}^{*}$, respectively, in meat. Moreover, infrared spectroscopy has been proposed by Ordolff (2006) for the detection of abnormal milk color in the blue region; for example, milk with a reddish color indicates contamination with blood that might be related to udder infection or teat injuries (Hettinga et al., 2008).

\section{Phenotypic Correlations}

Protein and casein were strongly correlated with each other (0.88), and therefore similar correlations between the color traits $\left(\mathrm{L}^{*}, \mathrm{a}^{*}, \mathrm{~b}^{*}\right)$ with both protein and casein were expected. Correlations between milk fat and $b^{*}$ and between milk protein and $\mathrm{a}^{*}$ in the present study were in agreement with those reported by Solah et al. (2007), who also reported significant correlations between these traits. Moreover, the correlation between MIRS-predicted lactose content and MIRS-predicted $b^{*}$ reported in the present study $(-0.21)$ was weaker than that reported by Gross et al. (2014) in colostrum $(-0.44)$.

\section{CONCLUSIONS}

This study demonstrates that MIRS data could be used as a screening tool to efficiently determine the $\mathrm{b}^{*}$ color of milk at a population level, providing a useful tool for the dairy industry and aiding in feeding management and selective breeding. One potential use of the equations developed in the present study is in milk cooperatives selecting specific farms that produce milk with certain milk color characteristics, which could demand a premium milk price. The MIRS prediction equations could be used to routinely monitor herd average milk color for recruiting or expelling producers from this scheme. Further investigation is, however, required to estimate the genetic variance of milk color, which will indicate the usefulness of the developed MIRS models for practical animal breeding purposes.

\section{ACKNOWLEDGMENTS}

Funding for this work was received from the Irish Department of Agriculture, Food and the Marine, Research Stimulus Fund project 11/SF/311, Breed Quality. The authors gratefully acknowledge the laboratory assistance of Owen Kenny (Teagasc, Food Research Centre, Moorepark, Fermoy, Co. Cork, Ireland).

\section{REFERENCES}

Calderon, F. B., P. Chaveau-Duriot, B. Pradel, B. Martin, M. Graulet, P. Doreau, and P. Noziere. 2007. Variations in carotenoids, vitamins A and E, and colour in cow's plasma and milk following a shift from hay diet to diets containing increasing levels of cartenoids and vitamin E. J. Dairy Sci. 90:5651-5664. 
Casalis, J., Y. Chardon, F. M. Luquet, P. Mainguy, and M. Yver. 1972. Sur la relation entre la teneur en beta-carotene et la couleur des beurres francais. Lait 52:28-42.

CIELAB. 1976. CIELAB Colour System. Commission International de l'Eclairage, Paris, France.

De Marchi, M., M. Penasa, M. Battagin, E. Zanetti, C. Pulici, and M. Cassandro. 2011. Feasibility of the direct application of near-infrared reflectance spectroscopy on intact chicken breasts to predict meat color and physical traits. Poult. Sci. 90:1594-1599.

De Marchi, M., V. Toffanin, M. Cassandro, and M. Penasa. 2013. Prediction of coagulating and non-coagulating milk samples using mid-infrared spectroscopy. J. Dairy Sci. 96:4707-4715.

De Marchi, M., V. Toffanin, M. Cassandro, and M. Penasa. 2014. Invited review: Mid-infrared spectroscopy as a phenotyping tool for milk traits. J. Dairy Sci. 97:1171-1186.

Espada, E., and H. Vijverberg. 2002. Milk colour analysis as a tool for the detection of abnormal milk. North American Conference on robotic milking, Toronto, Canada 20-22 March 2002: 28-38.

Gross, J. J., E. C. Evelyne, C. Kesslera, and R. M. Bruckmaier. 2014. Colour measurement of colostrum for estimation of colostral IgG and colostrum composition in dairy cows. J. Dairy Res. 81:440444.

Hettinga, K. A., H. J. F. van Valenberg, T. J. G. M. Lam, and A. C. M. van Hooijdonk. 2008. Detection of mastitis pathogens by analysis of volatile bacterial metabolites. J. Dairy Sci. 91:3834-3839.

Hutchings, J. B. 1994. Food Colour and Appearance. Blackie Academic, London, UK.

Keen, A. R., and R. D. Wilson. 1992. Effect of breed on colour and flavour. Pages 50-54 in Summary of Proceedings of the Milk Fat Flavour Forum. New Zealand Dairy Research Institute, Palmerston North, New Zealand.

Larsen, M. K., U. Kidmose, T. Kristensen, P. Beaumont, and G. Mortensen. 2013. Chemical composition and sensory quality of bovine milk as affected by type of forage and proportion of concentrate in the feed ration. J. Sci. Food Agric. 93:93-99.

Lucas, A., D. Andueza, E. Rock, and B. Martin. 2008. Prediction of dry matter, fat, $\mathrm{pH}$, vitamins, minerals, carotenoids, total antioxidant capacity, and color in fresh and freeze-dried cheeses by visible-near-infrared reflectance spectroscopy. J. Agric. Food Chem. $56: 6801-6808$.
McParland, S., E. Lewis, E. Kennedy, S. G. Moore, B. McCarthy, M. O'Donovan, S. T. Butler, J. E. Pryce, and D. P. Berry. 2014. Mid-infrared spectrometry of milk as a predictor of feed intake and efficiency in lactating dairy cows. J. Dairy Sci. 97:5863-5871.

Noziere, P., B. Graulet, A. Lucas, B. Martin, P. Grolier, and M. Doreau. 2006a. Carotenoids for ruminants: From forages to dairy products. Anim. Feed Sci. Technol. 131:418-450.

Noziere, P., P. Grolier, D. Durand, A. Ferlay, P. Pradel, and B. Martin. 2006b. Variations in carotenoids, fat-soluble micronutrients, and color in cows' plasma and milk following changes in forage and feeding level. J. Dairy Sci. 89:2634-2648.

Ordolff, D. 2006. Aussagekraft von standard-milchinhaltsstoffen zur bewertung der eutergesundheit. Landtechnik 61:48-49.

Phillips, L. G., M. L. McGiff, D. M. Barbano, and H. T. Lawless. 1995. The influence of fat o the sensory properties, viscosity, and color of lowfat milk. J. Dairy Sci. 78:1258-1266.

Raty, J. A., and K. E. Peiponen. 1999. Reflectance study of milk in the UV-visible range. Appl. Spectrosc. 53:1123-1127.

Solah, V. A., V. Staines, S. Honda, and H. A. Limley. 2007. Measurement of milk color and composition: Effect of dietary intervention on Western Australian Holstein-Friesian cow's milk quality. J. Food Sci. 72:S560-S566.

Soyeurt, H., F. Dehareng, N. Gengler, S. McParland, E. Wall, D. P. Berry, M. Coffey, and P. Dardenne. 2011. Mid-infrared prediction of bovine milk fatty acids across multiple breeds, production systems, and countries. J. Dairy Sci. 94:1657-1667.

Urbano-Cuadrado, M., M. D. Luque de Castro, P. M. Pérez-Juan, J. García-Olmo, and M. A. Gómez-Nieto. 2004. Near infrared reflectance spectroscopy and multivariate analysis in enology: Determination or screening of fifteen parameters in different types of wines. Anal. Chim. Acta 527:81-88.

Williams, P. 2007. Statistical terms for evaluation of accuracy and precision. Pages: 5-1-5-17 in Near Infrared Technology-Getting the Best out of Light, 5.0 ed. PDK Gran Nanaimo, Winnipeg, Manitoba, Canada.

Winkelman, A. M., D. L. Johnson, and A. K. H. MacGibbon. 1999. Estimation of heritabilities and correlations associated with milk color traits. J. Dairy Sci. 82:215-224. 